\title{
Hereditary hyperferritinemia-cataract syndrome
}

INSERM

\section{Source}

INSERM. (1999). Orphanet: an online rare disease and orphan drug data base. Hereditary hyperferritinemia-cataract syndrome. ORPHA:163

Hereditary hyperferritinemia with congenital cataracts is characterized by the association of early onset (although generally absent at birth) cataract with persistently raised plasma ferritin concentrations in the absence of iron overload. 